\title{
PENINGKATKAN AKTIVITAS DAN HASIL BELAJAR IPA POKOK BAHASAN MACAM-MACAM GAYA MENGGUNAKAN METODE EKSPERIMEN PADA SISWA KELAS IV SDN 1 DUWET KABUPATEN SITUBONDO
}

\author{
Moh. Nuril Hudha ${ }^{1)}$ \\ 1) Universitas Abdurachman Saleh Situbondo \\ airvillageband@gmail.com
}

\begin{abstract}
ABSTRAK: Pendidikan IPA di kelas IV SDN I Duwet memiliki kendala yaitu aktivitas siswa yang menurun dan hasil belajar yang kurang sehingga diperlukan perbaikan yaitu dengan menggunakan metode eksperimen dalam meningkatkan aktivitas dan hasil belajar siswa kelas 4 di SDN 1 Duwet. Hasil belajar siswa dengan menggunakan metode eksperimen mengalami peningkatan yang signifikan dari siklus I ke siklus II. Pada siklus II hasil belajar siswa yang mengalami ketuntasan belajar sebanyak 14 siswa atau sebesar $80 \%$ hal ini meningkat dari siklus I yakni $60 \%$ menjadi $80 \%$ hal tersebut terjadi kenaikan $20 \%$ dari keseluruhan. Berdasarkan hasil analisis data dan pembahasan, maka dapat disimpulkan bahwa pembelajaran IPA dengan menggunakan metode eksperimen pada pada pokok bahasan macam-macam gaya dapat meningkatkan aktivitas dan meningkatkan pemahaman siswa terhadap materi yang telah diajarkan sehingga hasil belajar juga meningkat.
\end{abstract}

Kata kunci : Eksperimen, Aktivitas, dan PTK.

ABSTRACT: Natural Science education in class IV SDN I Duwet has constraints namely decreased student activity and learning outcomes that are lacking so that improvement is needed by using the experimental method in increasing the activity and learning outcomes of grade 4 students in SDN 1 Duwet. Student learning outcomes using the experimental method experienced a significant increase from cycle I to cycle II. In cycle II the learning outcomes of students who experienced mastery learning by 14 students or by $80 \%$ this increased from cycle I ie $60 \%$ to $80 \%$ it was an increase of $20 \%$ of the overall. Based on the results of data analysis and discussion, it can be concluded that learning science by using experimental methods on the subject of various styles can increase activities and increase students' understanding of the material being taught so that learning outcomes also increase.

Keywords: Experiments, Activities, and CAR.

\section{PENDAHULUAN}

Rendahnya mutu pendidikan merupakan hal yang sangat sulit terpecahkan. Ada banyak faktor yang mempengaruhi rendahnya mutu pendidikan tersebut, salah satunya adalah proses pembelajaran yang melibatkan peserta didik. Inti dari proses pembelajaran adalah kegiatan belajar peserta didik. Frekuensi kegiatan belajar banyak dipengaruhi oleh pendekatan belajar yang baik, dimana hendaknya melibatkan peserta didik untuk aktif dalam kegiatan pembelajaran. Salah satu masalah yang memerlukan perhatian dalam kegiatan belajar mengajar adalah metode pembelajaran yang digunakan guru dalam 
pembelajaran, dalam hal ini guru masih menggunakan metode konvensional yaitu metode ceramah. Metode pembelajaran yang baik dan bervariasi diharapkan dapat mengembangkan potensi peserta didik secara utuh yang mencakup pengetahuan, keterampilan dan sikap.

Peningkatan mutu pendidikan dapat tercapai secara optimal. Untuk membuat siswa menyenangi suatu mata pelajaran yang diajarkan, guru harus kreatif dan dituntut untuk menciptakan kreativitas siswa. Menciptakan situasi pembelajaran yang nyaman dapat dilakukan dengan mengarahkan secara optimal sumber daya manusia dalam hal ini guru dan siswa, sumber daya alam yaitu segala sesuatu yang ada dilingkungan untuk dijadikan bahan pembelajaran dan sumber dana yang ada dalam mempersiapkan sarana dan prasarana pembelajaran. Disinilah tantangan seorang guru agar bisa meramu pembelajaran menjadi lebih menarik dan menyenangkan.

Seorang guru benar-benar dituntut untuk kreatif dan inovatif dalam menciptakan situasi belajar yang menyenangkan khususnya mata pelajaran IPA. Sebagaimana yang telah diketahui IPA mempelajari sifat-sifat dan gejala-gejala alam. Dalam mempelajari fenomena alam biasanya dilakukan pengamatan dan percobaan-percobaan untuk memperoleh informasi berupa fakta dan data. Di sekolah dasar siswa harus didekatkan dengan hal-hal yang bersifat kongkrit dalam penanaman konsep dasar. Siswa sekolah dasar secara psikologis lebih suka bermain dari pada belajar. Ditegaskan oleh Edgar Dale (dalam Dimyati dan Mudjiono, 1999:45) belajar yang paling baik bagi anak adalah belajar sambil bermain. Guru harus masuk pada dunia anak untuk menemukan formulasi pembelajaran dengan tingkat pencapaian yang optimal.

Guru sebagai faktor penentu dan paling berpengaruh dalam hal menanamkan konsep terhadap siswa. Penguasaan guru terhadap materi pelajaran, kemampuan guru dalam memilih dan menggunakan metode pembelajaran serta kemampuan guru dalam menetapkan media pembelajaran sangat menentukan terhadap keberhasilan proses pembelajaran, di samping adanya potensi dan kemauan siswa sendiri.

Lembaga pendidikan Sekolah Dasar sebagai salah satu lembaga pendidikan dasar yang menjadi pondasi dari lembaga pendidikan yang lebih tinggi tingkatannya. Lembaga pendidikan dasar sangat diharapkan mampu untuk menciptakan mutu lulusan pendidikan yang berkualitas dan berkompetensi, sehingga siswa SD mampu untuk melanjutkan ke jenjang pendidikan yang lebih tinggi tingkatannya dengan mutu yang baik. Dari peningkatan mutu dan kualitas lulusan sangat erat kaitannya dengan kondisi sekolah dan tugas guru sebagai pelaksana pendidikan yang langsung berinteraksi dengan siswa di kelas, maka gurupun dituntut untuk mampu mengembangkan dirinya secara profesional yang berkaitan dengan tugasnya .

Sebagai guru kelas SD dalam melaksanakan tugas masih banyak menemui berbagai masalah, diantaranya banyak pokok bahasan dari setiap mata pelajaran yang belum sepenuhnya dikuasai siswa sesuai dengan standar kompetensi yang diharapkan. Kendala yang dihadapi tidak hanya masalah mutu dan kualitas siswa, tetapi menyangkut 
komponen secara umum sebagai salah satu lembaga pendidikan. Kurikulum pelajaran yang selalu mengalami perubahan dan penyempurnaan menjadi suatu kendala bagi guru dalam pelaksanaan pembelajaran.

Pembelajaran di SD khususnya kelas IV pada mata pelajaran IPA yang memuat materi macam-macam gaya. Adapun standar kompetensi intinya (KI) adalah Memahami pengetahuan faktual dengan cara mengamati (mendengar, melihat, membaca) dan menanya berdasarkan rasa ingin tahu tentang dirinya, makhluk ciptaan Tuhan dan kegiatannya, dan benda-benda yang dijumpainya di rumah, sekolah, dan tempat bermain. Sedangkan kompetensi dasarnya (KD) adalah Mengidentifikasi macam-macam gaya, antara lain: gaya otot, gaya listrik, gaya magnet, gaya gravitasi, dan gaya gesekan. Pada materi tersebut penguasaan materi siswa SDN 1 Duwet masih rendah atau belum berhasil dengan baik hal ini dibuktikan dengan nilai hasil ulangan siswa yang rendah yaitu $80 \%$ atau 14 siswa nilainya masih dibawah $\mathrm{KKM}(>65)$, sedangkan siswa yang tuntas atau di atas KKM sebanyak 4 siswa atau sebesar $20 \%$.

Dari hasil observasi awal di SDN 1 Duwet pada kelas IV khususnya pada pembelajaran IPA, dapat disimpulkan bahwa guru lebih menitik beratkan pada pendekatan klasikal dan konvensional tanpa ada pendekatan aktif, dan inovatif, sehingga siswa tidak ikut aktif dalam pembelajaran. Hal ini ditegaskan oleh aktivitas siswa yang rendah dalam pembelajaran yaitu hanya terdapat 10 siswa yang sangat aktif dan aktif atau sebesar $60 \%$, sedangkan siswa yang kurang aktif dan cukup aktif sebanyak 8 siswa atau sebesar $40 \%$. Berdasarkan masalah di atas maka guru dan peneliti bermaksud untuk memecahkan permasalahan tersebut yaitu dengan melakukan perbaikan dalam proses pembelajaran IPA pokok bahasan macam-macam gaya dengan menggunakan metode pembelajaran yang sesuai dan menarik, sehingga dapat meningkatkan aktivitas dan hasil belajar siswa.

Salah satu metode pembelajaran yang dapat meningkatkan aktivitas dan hasil belajar siswa dalam pembelajaran IPA pokok bahasan penghantar panas yaitu dengan menggunakan metode eksperimen. Metode eksperimen sangatlah relevan dan cocok digunakan pada mata pelajaran IPA kelas IV pokok bahasan macam-macam gaya. Metode eksperimen memberi kesempatan siswa untuk mengalami sendiri atau melakukan sendiri, mengikuti proses, mengamati suatu obyek, menganalisis, keadaan atau suatu proses tertentu, membuktikan dan menarik kesimpulan sendiri tentang materi yang mereka pelajari yaitu pokok bahasan macam-macam gaya. Sementara peranan guru dalam metode eksperimen adalah memberi bimbingan agar eksperimen bisa dilakukan dengan teliti sehingga tidak terjadi kekeliruan atau kesalahan.

\section{Rumusan masalah}

Berdasarkan pada latar belakang, permasalahan dalam penelitian ini dapat di rumuskan sebagai berikut: 
a. Bagaimanakah peningkatan aktivitas belajar IPA dengan metode eksperimen pokok bahasan macam-macam gaya pada siswa kelas IV SDN 1 Duwet Tahun Pelajaran 2018/2019?

b. Bagaimanakah peningkatan hasil belajar IPA dengan metode eksperimen pokok bahasan macam-macam gaya pada siswa kelas IV SDN 1 Duwet Tahun Pelajaran $2018 / 2019$ ?

\section{Tujuan Penelitian}

Berdasarkan rumusan masalah, maka tujuan yang ingin dicapai dalam penelitian ini adalah sebagai berikut

a. Meningkatkan aktivitas belajar IPA dengan metode eksperimen pokok bahasan macam-macam gaya pada siswa kelas IV SDN 1 Duwet Tahun Pelajaran 2018/2019.

b. Meningkatkan hasil belajar IPA dengan metode eksperimen pokok bahasan macammacam gaya pada siswa kelas IV SDN 1 Duwet Tahun Pelajaran 2018/2019.

\section{METODE PENELITIAN}

Metode penelitian adalah suatu cara yang dipergunakan untuk mencapai suatu tujuan penelitian. Dalam bab ini akan membahas secara rinci komponen-komponen metode penelitian yang akan digunakan dalam penelitian ini. Adapun metode penelitian yang akan dibahas meliputi waktu dan tempat penelitian, subjek penelitian, definisi operasional penelitian, rancangan penelitian, prosedur penelitian, metode pengumpulan data, analisis data dan indikator ketercapainan kinerja.

\section{Waktu dan Tempat Penelitian}

Tempat penelitian ini dilaksanakan di SDN 1 Duwet pada semester genap tahun pelajaran 2018/2019 .

\section{Subjek Penelitian}

Penentuan subjek penelitian ditetapkan sendiri oleh peneliti. Adapun subjek dari penelitian ini adalah siswa kelas IV SDN 1 Duwet 2018/2019, yang berjumlah 18 siswa yang memiliki kemampuan yang heterogen.

\section{Definisi Operasional}

Untuk menghindari salah pengertian dalam penelitian ini, maka perlu dijelaskan definisi operasional. Variabel-variabel yang perlu dijelaskan dalam penelitian ini yaitu:

a. Metode eksperimen

Metode eksperimen adalah metode yang memberikan kesempatan pada siswa perorangan atau kelompok untuk dilatih melakukan suatu proses atau percobaan sehingga mereka mempunyai ketrampilan. Metode eksperimen diukur dengan kemampuan guru dalam menerapkan metode eksperimen sesuai dengan prosesdur yang telah direncanakan. 
b. Aktivitas belajar siswa

Aktifitas belajar siswa meliputi bertanya, bekerjasama dalam kelompok, siswa berekperimen dan siswa mengerjakan tugas yang diberikan guru.

c. Hasil belajar

Hasil belajar adalah kemampuan-kemampuan yang dimiliki siswa setelah ia menerima pengalaman belajarnya melalui tes dengan melibatkan kegiatan fisik maupun mental.

\section{Rancangan Penelitian}

Rancangan penelitian yang digunakan dalam penelitian ini adalah penelitian tindakan kelas (PTK) atau Classroom Action Research (CAR). Dalam penelitian ini menggunakan model skema penelitian Hopskin dimana penelitian tindakan dilaksanakan berupa proses pengkajian berdaur (cyclical) yang terdiri dari empat tahap (Tim Pelatih Proyek PGSM, 1999:8).

Siklus dalam penelitian tindakan kelas ini direncanakan menggunakan 2 (dua) siklus yang diawali dengan perencanaan (planning), penerapan tindakan (action), observasi (observation), dan refleksi (reflection). Apabila pada siklus I aktivitas dan hasil belajar siswa mencapai dan belum mencapai ketuntasan maka penelitian ini tetap dilanjutkan pada siklus II dan apabila pada siklus II belum mencapai ketuntasan aktivitas dan hasil belajar maka penelitian ini dihentikan dan tidak dilanjutkan pada siklus III.

\section{Prosedur Penelitian}

Penelitian tindakan diawali dengan pendahuluan kemudian pelaksanaan tindakan yang meliputi: perencanaan, tindakan, observasi dan refleksi untuk mengetahui ketuntasan hasil belajar siswa.

\section{Metode Pengumpulan Data}

Metode pengumpulan data yang tepat merupakan salah satu syarat kesempurnaan penelitian untuk mendapatkan data atau informasi yang tepat dan akurat. Sesuai dengan tujuan penelitian yang ingin dicapai, maka metode yang digunakan dalam penelitian ini adalah studi eksplorasi. Studi eksplorasi digunakan untuk mengkaji lebih mendalam ketercapaian hasil. Metode yang digunakan dalam penelitian ini adalah obsevasi, wawancara, dokumentasi dan test.

a. Observasi

Observasi adalah tekhnik pengumpulan data yang diperoleh dengan jalan mencatatat secara sistematika fenomena-fenomena yang diselidiki. Observasi dilaksanakan antara lain untuk mengetahui aktivitas siswa. Hal-hal yang diobservasi dalam penelitian ini adalah bertanya, kerjasama, melakukan eksperimen pokok bahasan penghantar panas, membuat kesimpulan, mengerjakan tugas. 
b. Wawancara

Penelitian ini metode wawancara digunakan untuk mengetahui tanggapan siswa dan guru mengenai pelaksanaan pembelajaran. Metode ini dibagi menjadi dua yaitu wawancara langsung dan tidak langsung. Wawancara langsung adalah wawancara yang dilakukan secara langsung dengan orang yang diwawancarai tanpa melalui perantara. Wawancara tidak langsung apabila pewawancara dan orang yang diwawancarai tidak bertemu secara langsung melainkan melalui perantara. Pengambilan data dalam penilitian ini menggunakan wawancara langsung dengan siswa untuk mengetahui sejauh mana peserta didik dalam mengikuti pembelajaran IPA mengetahui apakah tertarik dengan pembelajaran tersebut. Wawancara juga dilakukan dengan guru IPA dimana yang sekaligus sebagai guru kelas.

Wawancara yang digunakan dalam penelitian ini adalah wawancara bebas terpimpin, dimana peneliti sudah menyiapkan terlebih dahulu pertanyaan yang akan diajukan responden. Data yang diperoleh dari metode wawancara akan digunakan untuk melengkapi dan mendukung data utama dalam penelitian.

\section{c. Dokumentasi}

Dokumentasi adalah alat yang digunakan untuk mencari data mengenai hal-hal atau variable yang berupa catatan, transkrip, surat kabar, majalah, prasasti,notulen, rapat, leger, agenda dan sebagainya (Arikunto, 1998:236). Dokumentasi digunakan sebagai alat yang tepat dan cepat untuk mencatat hasil observasi dan dapat mengetahui langsung keadaan yang sesuai dengan kemampuan siswa. Data yang ingin diperoleh dalam penelitian ini meliputi : data siswa yang berisi nama, jenis kelamin dan jumlah siswa kelas VI SDN 1 Duwet.

d. Tes

Menurut Arifin (1991:22), tes adalah teknik atau cara dalam rangka melaksanakan kegiatan evaluasi, yang didalamnya terdapat berbagai item atau serangkaian tugas yang harus dikerjakan atau dijawab oleh anak didik, kemudian pekerjaan dan jawaban itu menghasilkan nilai tentang perilaku anak tersebut. Dalam penelitian ini jenis tes yang digunakan adalah tes akhir. Tes akhir berupa soal pilihan ganda dan uraian (essay) dengan tujuan untuk mengetahui hasil belajar siswa.

\section{Analisis Data}

Analisis data merupakan langkah yang menentukan dalam suatu penelitian. Walaupun langkah-langkah penelitian terlaksana dengan baik tetapi jika analisa datanya tidak relevan, maka kesimpulan yang diperoleh bisa salah dan tidak relevan. Metode analisa data yang digunakan dalam penelitian ini adalah metode diskriptif. Data kuantitatif yang berbentuk angka dan kualitatif yang dinyatakan dengan kata-kata atau simbol. Analisis deskriptif menggambarkan bahwa dengan tindakan yang dilakukan dapat menimbulkan adanya perbaikan, peningkatan, dan perubahan ke arah yang lebih baik dibandingkan dengan keadaan sebelumnya. Data yang bersifat kualitatif, disisihkan untuk 
sementara karena sangat berguna untuk melengkapi gambaran yang diperoleh dari analisis data kuantitatif.

\section{HASIL DAN PEMBAHASAN}

\section{Tindakan Pendahuluan}

Tindakan pendahuluan pada penelitian ini adalah sebagai berikut :

a. diserahkan surat ijin penelitian kepada Kepala sekolah SDN 1 Duwet untuk mengadakan penelitian di kelas IV dengan metode eksperimen.

b. diadakan wawancara dengan guru kelas IV untuk mengetahui metode yang digunakan guru pada saat proses pembelajaran, mengetahui informasi hasil belajar siswa, hambatan dan kesulitan yang dihadapi oleh siswa selama proses pembelajaran, menentukan jadwal penelitian.

\section{Gambaran Umum SDN 1 Duwet}

SDN 1 Duwet terletak di Desa Duwet Kecamatan Panarukan Kabupaten Situbondo. Tenaga pengajar yang dimiliki oleh SDN 1 Duwet berjumlah 12. Sarana dan prasarana yang dimiliki SDN 1 Duwet sudah cukup lengkap yaitu memiliki 6 ruang kelas. Selain itu juga terdapat 1 ruang UKS, 1 ruang perpustakaan, 1 ruang guru, dan 2 kamar mandi. Gambaran umum tentang kegiatan belajar mengajar dalam pembelajaran IPA yang dilakukan di kelas IV SDN 1 Duwet sudah cukup baik. Hal ini dapat terlihat dari beberapa komponen yang terlibat dalam kegiatan belajar mengajar yaitu guru, siswa, dan fasilitas belajar yang tersedia. Dilihat dari sisi guru, dapat diketahui bahwa metode yang sering diterapkan oleh guru dalam proses belajar mengajar, yaitu metode ceramah, tanya jawab dan pemberian tugas. Media pembelajaran yang digunakan oleh guru dalam pembelajaran menggunakan media papan tulis. Saat guru berceramah siswa mendengarkan dan mencatat materi yang dijelaskan, kemudian guru memberikan kesempatan pada siswa untuk bertanya tentang hal-hal yang berhubungan dengan materi yang kurang atau tidak dimengerti siswa. Hal ini menunjukkan bahwa kegiatan belajar mengajar di kelas IV belum menampakkan adanya interaksi yang aktif secara menyeluruh antara guru dengan siswa dan siswa dengan siswa.

\section{Pelaksanaan Tindakan}

\section{Prasiklus}

Kegiatan prasiklus dilakukan menggunakan metode diskusi dengan pokok bahasan macam-macam gaya yang dilakukan oleh guru kelas IV. Kegiatan prasiklus ini bertujuan untuk mengetahui pengetahuan siswa dan pemahaman awal siswa tentang materi IPA sebelum penerapan pembelajaran dengan menggunakan metode eksperimen.

Berdasarkan hasil observasi aktivitas siswa pada prasiklus diketahui presentase aktivitas siswa secara klasikal adalah $40 \%$ hal tersebut menunjukkan bahwa aktivitas siswa masih rendah. Dalam pembelajaran siswa hanya diam, mendengarkan penjelasan dari guru dan mencatat materi yang ditulis oleh guru di papan selanjutnya siswa mendapat 
tugas dari guru. Hasil belajar siswa secara klasikal pada prasiklus yaitu 20\%, dari presentasi tersebut menunjukkan bahwa hasil belajar yang dicapai siswa masih rendah.

\section{Siklus I}

a. Perencanaan

Kegiatan yang dilakukan sesuai dengan rencana yang telah ditetapkan sebelumnya, yaitu dengan kegiatan berikut.

1) Menyusun rencana pelaksanaan pembelajaran dengan pokok bahasan macammacam gaya.

2) Menyiapkan materi dan bahan ajar dan perlengkapan yang akan digunakan dalam pembelajaran dan menyusun alat evaluasi berupa LKS dan post tes.

3) Menyusun lembar observasi aktivitas siswa.

4) Menyusun lembar observasi aktivitas guru.

5) Membuat lembar wawancara pada guru dan siswa untuk mengetahui kesulitan yang dihadapi siswa dalam materi IPA.

b. Tindakan

Kegiatan yang dilakukan pada tahap tindakan adalah melaksanakan proses belajar mengajar pokok bahasan macam-macam gaya sesuai dengan rencana pelaksanaan pembelajaran yang telah dirancang. Pelaksanaannya terdiri dari 3 tahap, yaitu kegiatan awal, kegiatan inti, dan kegiatan akhir. Berikut penjelasan dari ketiga tahap tersebut.

1) Kegiatan Awal

a) Guru menyiapkan peralatan dan bahan yang akan digunakan sebelum pembelajaran

b) Guru mengucapkan salam

c) Guru mengabsen

d) Guru menyampaikan tujuan pembelajaran dan metode yang akan digunakan dalam pembelajaran

e) Apersepsi

2) Kegiatan Inti

a) Guru membagi siswa menjadi beberapa kelompok kecil yang terdiri dari 3 - 5 orang siswa heterogen;

b) Guru membagikan dan menjelaskan prosedur eksperimen yang akan dilakukan.

c) Siswa melakukan eksperimen macam-macam gaya.

d) Siswa mencatatat hasil pengamatan pada lembar kerja siswa.

e) Siswa membuat laporan dan tanggapan serta membuat kesimpulan.

f) Siswa diberi tes individu untuk mengetahui sejauh mana pemahaman siswa tentang materi;

3) Kegiatan Akhir

a) Pada kegiatan akhir, guru memberikan penghargaan kepada kelompok yang dapat membedakan macam-macam gaya dengan benar.

b) Membuat kesimpulan dari pembelajaran yang telah dilakukan. 


\section{c) Salam}

\section{c. Observasi}

Kegiatan observasi dilaksanakan bersamaan dengan pelaksanaan tindakan. Kegiatan observasi bertujuan untuk mengamati tingkah laku siswa selama proses pembelajaran berlangsung serta untuk mengamati cara guru mengajar dengan berpedoman pada lembar observasi yang telah disiapkan oleh peneliti. Hal ini dilakukan untuk memperoleh gambaran mengenai pelaksanaan pembelajaran IPA pokok bahasan macam-macam gayadengan metode eksperimen. Observasi dibantu oleh tiga orang observer yang terdiri dari guru kelas dan dua orang teman sejawat.

1) Observasi Aktivitas Guru

Dari observasi yang dilakukan oleh observer diperoleh hasil observasi terhadap aktivitas guru sebesar $80 \%$ atau kategori lancar. Dengan demikian dapat diketahui bahwa seluruh kegiatan guru selama proses pembelajaran siklus I berlangsung telah sesuai dengan prosedur rencana pelaksanaan pembelajaran. Namun masih terdapat kekurangan yang harus diperbaiki pada pembelajaran siklus selanjutnya yaitu terdapat tanggapan dari observer untuk melakukan bimbingan pada setiap individu saat proses melakukan eksperimen. Hal ini dimaksudkan agar siswa mendapatkan bimbingan lebih intensif oleh guru dalam melakukan eksperimen.

2) Observasi Aktivitas Siswa

Observasi aktivitas siswa dilakukan observer, yaitu dua teman sejawat. Hasil observasi aktivitas siswa pada siklus I dapat diperoleh prosentase aktivitas siswa yakni sebesar $60 \%$. Hal ini menunjukkan bahwa aktivitas siswa siklus I termasuk pada kategori aktif.

d. Refleksi

Kegiatan yang dilakukan pada tahap refleksi adalah mengkaji ulang hasil pelaksanaan siklus I untuk menentukan langkah perbaikan pada siklus II. Adapun hasil kegiatan meliputi : prosentase aktivitas siswa secara klasikal yaitu sebesar 60\%. Siswa yang tergolong dalam kategori sangat aktif berjumlah 0 orang $(0 \%)$, siswa yang tergolong aktif berjumlah 10 orang (60\%), siswa yang tergolong cukup aktif berjumlah 4 orang (20\%), sedangkan siswa yang tergolong kurang aktif berjumlah 4 orang (20\%). Hal ini menunjukkan bahwa aktivitas siswa siklus I termasuk pada kategori cukup aktif. Dari segi hasil belajar dapat diketahui . Hal ini berarti ketuntasan belajar individual mencapai $60 \%$. Sedangkan siswa yang belum mencapai ketuntasan belajar sebanyak 8 siswa atau 40\%. Jika dibandingkan dengan hasil belajar sebelum dilakukan tindakan, hasil belajar siswa mengalami peningkatan yang sangat signifikan. Akan tetapi, hasil tersebut masih belum mencapai ketuntasan klasikal seperti yang telah ditetapkan yaitu $75 \%$. Berdasarkan hasil refleksi, maka peneliti mengadakan siklus II, diharapkan aktivitas dan hasil belajar siklus II lebih baik dan meningkat. 


\section{Siklus II}

Siklus II dilaksanakan sesuai dengan hasil refleksi dari kekurangan dan kelebihan pada siklus I.

a. Perencanaan

Perencanaan pada siklus II dibuat berdasarkan hasil analisis dan refleksi pada pembelajaran siklus I, untuk itu beberapa instrument penelitian yang perlu diperbaiki yaitu :

1) Menyusun rencana pelaksanaan pembelajaran (RPP Perbaikan Siklus II) dengan pokok bahasan macam-macam gaya.

2) Menyiapkan materi dan bahan ajar dan perlengkapan yang akan digunakan dalam pembelajaran.

3) Menyusun alat evaluasi berupa LKS dan post tes untuk mengetahui hasil belajar siswa.

4) Menyusun lembar observasi aktivitas siswa.

5) Menyusun lembar observasi aktivitas guru.

6) Membuat lembar wawancara pada guru dan siswa untuk mengetahui kesulitan yang dihadapi siswa dalam materi IPA.

b. Tindakan

1) Kegiatan Awal

a) Guru menyiapkan peralatan dan bahan yang akan digunakan sebelum pembelajaran

b) Guru mengucapkan salam

c) Guru mengabsen.

d) Guru menyampaikan tujuan pembelajaran dan metode yang akan digunakan dalam pembelajaran

e) Apersepsi, mengingat materi sebelumnya tentang macam-macam gaya.

2) Kegiatan Inti

a) Guru membagi siswa menjadi beberapa kelompok kecil yang terdiri dari 3 - 5 orang siswa heterogen;

b) Guru membagikan dan menjelaskan prosedur eksperimen yang akan dilakukan.

c) Siswa melakukan eksperimen tentang gaya pegas.

d) Siswa mencatatat hasil pengamatan pada lembar kerja siswa.

e) Guru membimbing siswa selama siswa dengan kelompoknya melakukan eksperimen.

f) Siswa membuat laporan dan tanggapan serta membuat kesimpulan dari eksperimen yang telah dilakukan.

g) Siswa diberi tes individu untuk mengetahui sejauh mana pemahaman siswa tentang materi.

3) Kegiatan Akhir

a) Pada kegiatan akhir, guru memberikan penghargaan kepada kelompok terbaik. 
b) Menarik kesimpulan dari pembelajaran yang telah dilakukan.

\section{c. Observasi}

c) Salam penutup.

Pelaksanaan observasi pembelajaran sama dengan pelaksanaan siklus I, yaitu dibantu oleh dua orang observer bertugas mengamati aktivitas siswa dan guru dari awal sampai akhir pembelajaran. Adapun hasil observasi terhadap siswa dan guru adalah sebagai berikut.

\section{1) Observasi Aktivitas Guru}

Observasi terhadap aktivitas guru mengalami peningkatan. Guru sudah terlihat menyampaikan meteri pembelajaran sesuai dengan rencana pelaksanaan pembelajaran yang telah disusun. Pada saat memberikan penjelasan diselingi dengan tanya jawab yang membuat siswa lebih memperhatikan materi. Aktivitas guru pada siklus II diperoleh presentase sebesar $80 \%$ atau kategori sangat lancar.

Pada siklus II ini guru terlihat lebih membimbing dan memberikan arahan yang positif pada saat diskusi kelompok, presentasi dan menarik kesimpulan. Tujuannya agar siswa lebih disiplin dan bertanggungjawab akan tugas yang diberikan guru. Aktivitas guru yang baik ini memberikan dampak pada keaktifan siswa saat memperhatikan penjelasan guru, peningkatan kemampuan siswa dalam bertanya dan mengemukakan pendapat, melaksanakan diskusi kelompok dengan baik dan keberanian siswa dalam presentasi.

2) Observasi Aktivitas Siswa

Hasil observasi aktivitas siswa pada siklus II dapat diperoleh prosentase aktivitas siswa yakni sebesar 95\%. Hal ini menunjukkan bahwa aktivitas siswa siklus II termasuk pada kategori sangat aktif. Hasil observasi pada siklus II menunjukkan minat dan perhatian siswa sudah cukup baik, ditandai dengan antusias siswa ketika mengikuti proses pembelajaran. Pada saat guru menjelaskan materi siswa menyimak dengan seksama dan mencatat hal yang dianggap penting. Untuk kemampuan bertanya, siswa sudah menunjukkan keberaniannya hal ini ditunjukkan dengan siswa yang sering bertanya. Dalam pembelajaran terjadi interaksi positif antara siswa dengan siswa, siswa dengan guru dan siswa dengan meteri pelajaran.

Pada aspek melaksanakan eksperimen, terlihat kekompakan pada setiap kelompok ditunjukkan saat berdiskusi dengan anggotanya. Semua anggota aktif bekerja sesuai dengan tugasnya masing-masing, hanya ada beberapa siswa terlihat masih saja bermain-main. Pada kegiatan ini aktifitas siswa tetap dipantau oleh observer dengan memberikan bimbingan dan arahan agar siswa dapat memanfaatkan waktu yang diberikan dengan baik serta dapat melatih kedisiplinan dan tanggungjawab pada diri siswa. Pada kegiatan ini bimbingan guru sangatlah penting agar diskusi dapat berjalan lancar. 


\section{d. Refleksi}

Berdasarkan hasil pelaksanaan dan observasi yang telah dilakukan pada siklus II, maka dapat disimpulkan. Siswa sudah mulai aktif bertanya, kerjasama, melakukan eksperimen macam-macam gaya, dan mengerjakan tugas. Pelaksanaan post tes juga berjalan dengan lancar. Siswa sangat tenang dalam mengerjakan soal tes. Untuk prosentase ketuntasan aktivitas pada siklus II mencapai 95\%. Dan pada hasil belajar siswa dapat diketahui n jumlah siswa yang mengalami ketuntasan belajar sebanyak 14 siswa. Hal ini berarti ketuntasan belajar individual mencapai $80 \%$. Sedangkan siswa yang belum mencapai ketuntasan belajar sebanyak 4 siswa atau 20\%. Jika dibandingkan dengan hasil belajar sebelum dilakukan tindakan, hasil belajar siswa mengalami peningkatan yang sangat signifikan.

\section{PEMBAHASAN}

Penelitian ini merupakan penelitian tindakan kelas yang berawal dari permasalahan yang dihadapi guru di kelas IV SDN 1 Duwet pada mata pelajaran IPA yaitu siswa terlihat kurang memperhatikan penjelasan guru, siswa kurang aktif dalam pembelajaran serta terlihat bermain sendiri dengan teman sebangkunya. Berdasarkan permasalahan yang ada maka peneliti mencoba menggunakan metode eksperimen pada pokok bahasan macam-macam gaya dengan tujuan untuk meningkatkan aktivitas dan hasil belajar siswa. Metode ini diharapkan dapat membuat siswa lebih aktif dalam pembelajaran, dapat mengembangkan daya berpikirnya sendiri, daya kreatif, dan daya inisiatif.

Dalam penelitian ini dilaksanakan menggunakan dua siklus. Sebelum pelaksanaan siklus dilakukan, peneliti melakukan observasi terhadap guru dan siswa untuk mengetahui bagaimana aktivitas dan hasil belajar siswa serta cara guru menyampaikan materi dan mengetahui masalah yang ada di kelas IV. Dari hasil observasi tersebut peneliti kemudian melakukan prasiklus, dalam prasiklus pembelajaran yang dilakukan sama dengan pembelajaran yang biasa dilakukan oleh guru, dari pra siklus tersebut kemudian dijadikan sebagai dasar dalam penelitian ini. Berdasarkan temuan masalah pada prasiklus tersebut kemudian dilakukan siklus I untuk mencoba menerapkan metode yang baru untuk memperbaiki cara belajar yang dilakukan di kelas IV.

\section{Pembahasan hasil Siklus I}

Pada kegiatan pembelajaran, siswa dikelompokkan secara heterogen baik dari jenis kelamin, maupun kemampuan siswa yang didasarkan pada hasil tes prasiklus. Guru membagikan alat-alat yang akan digunakan bereksperimen dan menjelaskan prosedur eksperimen yang akan dilakukan serta lembar kerja kelompok. Siswa melakukan eksperimen tentang perpindahan panas. Siswa melakukan pengamatan dan mencatat hasilnya pada lembar kerja siswa, kemudian siswa membuat laporan dan menyimpulkan hasil eksperimennya. Pada saat pembelajaran berlangsung, observer melakukan penilaian 
terhadap aktivitas siswa dan guru. Setelah siswa selasai bereksperimen, guru menunjuk perwakilan dari tiap kelompok untuk kedepan kelas mempresentasikan kesimpulan dari eksperimen yang dilakukan.

Pada saat pembelajaran, siswa terlihat aktif dan senang mengikuti pembelajaran IPA dengan menggunakan metode eksperimen yang dapat dilihat dari hasil observasi terhadap aktivitas perhatian terhadap pelajaran, pada setiap pertemuan prosentasenya mengalami peningkatan. Prosentase aktivitas siswa secara klasikal pada siklus I termasuk kategori aktif. Walaupun pada awalnya kategori bertanya terlihat minim hal tersebut disebabkan karena selama ini siswa kurang termotivasi untuk berani bertanya dan mengeluarkan pendapat secara langsung, sehingga hanya beberapa siswa saja yang berani bertanya. Hasil observasi aktivitas siswa pada siklus I dapat diperoleh prosentase aktivitas siswa yakni sebesar $60 \%$.

Hasil belajar siswa dengan menggunakan metode eksperimen juga mengalami peningkatan yang signifikan pada siklus I yaitu siswa yang mengalami ketuntasan belajar sebanyak 10 siswa. Hal ini berarti ketuntasan belajar individual mencapai $60 \%$. Sedangkan siswa yang belum mencapai ketuntasan belajar sebanyak 8 siswa sebesar (40 $\%)$.

\section{Pembahasan hasil Siklus II}

Pada kegiatan pembelajaran, siswa dikelompokkan sesuai dengan siklus. Guru membagikan alat-alat yang akan digunakan bereksperimen dan menjelaskan prosedur eksperimen yang akan dilakukan serta lembar kerja kelompok. Siswa melakukan eksperimen tentang macam-macam gaya yaitu gaya pegas, gaya otot, gaya gravitasi.

Pelaksanaan tes akhir berjalan dengan lancar dan tertib, meskipun masih ada beberapa siswa yang bertanya dengan teman satu meja, tetapi langsung ditegur oleh guru/peneliti. Pada akhir penelitian juga masih ditemukan beberapa siswa yang belum biasa berinteraksi dengan teman satu kelompok, hal ini karena siswa tersebut merasa malu, takut salah dan tidak biasa menjelaskan kepada teman yang lain sehingga terkesan kurang akrab dengan teman kelompoknya. Oleh karena itu, perlu diadakan pendekatan terhadap kelompok yang kurang aktif untuk memberikan pengarahan serta bimbingan supaya mereka dapat bekerja sama dengan temannya. Pada siklus II siswa sudah tampak lebih aktif, jika dibandingkan dengan siklus I, sehingga untuk aktivitas dan hasil belajar siswa mengalami peningkatan yang signifikan sehingga siklus II sudah dikatakan berhasil. Prosentase ketuntasan aktivitas pada siklus II mencapai $80 \%$.

\section{KESIMPULAN}

Hasil belajar siswa dengan menggunakan metode eksperimen juga mengalami peningkatan yang signifikan dari siklus I ke siklus II. Pada siklus II hasil belajar siswa yang mengalami ketuntasan belajar sebanyak 14 siswa. Hal ini berarti ketuntasan belajar 
individual mencapai $80 \%$. Sedangkan siswa yang belum mencapai ketuntasan belajar sebanyak 4 siswa atau $20 \%$.

Hasil penelitian tersebut menunjukkan bahwa pembelajaran IPA dengan menggunakan metode eksperimen pada pada pokok bahasan macam-macam gaya dapat meningkatkan aktivitas dan meningkatkan pemahaman siswa terhadap materi yang telah diajarkan sehingga hasil belajar juga meningkat.

\section{DAFTAR RUJUKAN}

Arifin, Z., 1991. Evaluasi Intruksional, Prisip, teknik, prosedur. Bandung: PT Remaja Rosdakarya.

Arikunto, S. 1998. Prosedur Penelitian. Jakarta: Rineka Cipta

Depdiknas. 2006. Kurikulum Berbasis Kompetensi Dasar, Pengembangan Silabus Dan RPP Sekolah Dasar Kelas I-VI. Jakarta: Depdiknas.

Dimyati. dan Mudjiono. 1994. Belajar dan Pembelajaran. Jakarta: Depdikbud.

Dimyati dan Mudjiono. 1999. Belajar dan Pembelajaran. Jakarta : Rineka Cipta.

Djamarah dan Anwar, Z. 1996. Strategi Belajar Mengajar. Jakarta: Rineka Cipta.

Hamalik, O. 2005. Proses Belajar Mengajar. Bandung: Bumi Aksara 2009. Proses Belajar Mengajar. Bandung: Bumi Aksara

Hasibuan. 1995. Proses Belajar Mengajar. Bandung: remaja Rosdakarya.

Nurkancana, W, dan Sunartana. 1990. Evaluasi Pendidikan. Surabaya: Usaha Nasional.

Sardiman, A.M. 1987. Prinsip dan Teknik Evaluasi Pengajaran. Bandung: Remaja Rosdakarya.

Sardiman. A.M. 2001. Interaksi dan Motivasi Belajar Mengajar. Jakarta: Raja Grafindo Persada.

Siddiq. M. D, dkk 2008. Pengembangan Bahan Pembelajaran SD. Jakarta: Direktorat Jendral Pendidikan Tinggi Departemen Pendidikan Nasional.

Sudjana, N. 2002., Dasar-dasar Proses Belajar Mengajar. Bandung: Sinar Baru Algensindo.

Sudjana, N. 1991. Penilaian Hasil Proses Belajar Mengajar. Bandung: PT Remaja Rosdakarya

Sutrisno, L dkk 2007. Pengembangan Pembelajaran IPA SD. Jakarta: Direktorat Jendral Pendidikan Tinggi Depdiknas Jember: 18 April 2009

Tim Pelatih Proyek PGSM. 1999. Penelitian Tindakan kelas. Jakarta: Rineka Cipta.

Wayan dan Sunartana. 1990. Evaluasi Hasil Belajar. Surabaya: Usaha Nasional. 